\title{
NP（Nurse Practitioner）紹介
}

\section{愛知医科大学病院心臓外科における診療看護師の䚋状と課題について}

\author{
愛知医科大学病院心臓外科 \\ 診療看護師 牧野悟士 Satoshi Makino \\ 教授 松山克彦 Katsuhiko Matsuyama
}

愛知医科大学病院は愛知県の四大学病院の 1 つであり, 900 床の大規模大学病院として急性期医療を果たすかたわ ら，長久手市をはじめとした東尾張エリアの地域医療を担 う拠点病院としての役割も果たしています。藏外科では 年間約 150 例の心臟外科手術が行われ, 緊急症例が扰よそ $1 / 3$ を占めます.

当院では，2015 年から診療看護師（NP）が活動を開始 し，2021年 3 月現在 6 名の NP が在籍しており，そのう ち 2 名が卒後研修中, 3 名が麻酔科, 1 名が心臓外科に所 属しています。筆者は 2016 年に NP の資格を取得し， 3 年間の麻酔科勤務を経た後, 2019 年 5 月から心臟外科に 所属し，心臟外科 NP として勤務を開始しました。約 2 年 間の勤務を経て，多くの貴重な経験をさせていただくとと もに，困難な状況を経験して気づく課題もありました。 NPの資格を得るまでの経緯, NPとしてこれまでに経験 してきたこと，そこからみえてきた課題や今後の抱負につ いて述べさせていただき, 心臟外科領域における NP 導 入，活用の参考になれば幸いです.

私は 21 歳のときに看護師免許取得後，8 年間，手術室 看護師として手術室に勤務し, 心藏外科手術を含めたさま ざまな外科手術に携わってきました，手術室勤務では外科 手術の実際や麻酔管理の補助などを通し, 解剖学や循環動 態など得るところが非常に大きく, 勉強になりましたが, 一方で, 医師からの指示があるまで疼痛への対応ができな い, 血圧が下がっていても循環作動薬を看護師の判断で調 整することができない, 出血をしていても看護師が輸血療 法を決定することができないなどのジレンマを感じていま した。そうした中，米国オ八イオ州クリーブランドでNP として働くChristopher Manacci 氏の講演を聞く機会があ り, 米国におけるNPの診療内容, 特に日本では医師が行 うことである侵襲的な処置や投薬などの薬剤管理を米国で はNPが率先して行っている現状を聞き, 自分が目指す道 はこれだと確信しました。

しかし，日本における NP 教育課程への進学を決断する 際には不安がありました，1つ目は，キャリア形成に関す る問題で NPとしての昇進制度が確立されて抢らず，役職
への道が途絶えるということです，たとえば，現在私は心 臓外科配属の NPですが, あくまで看護部所属であり, 給 与体系や勤務体制などは役職のない看護師と同等になって います。この NPの待遇に関しては悩ましい問題であり, 当院においても検討中の課題です. 2 つ目は経済面に関す る問題で, 大学院が全日制となるため, 現職を休職もしく は退職する必要があり, さらに, 在学中の生活費打よび大 学院の学費を捻出しなければならないということです。こ れに関しては, 4 年間の当院勤務の義務が付きますが, 病 院が提供している奨学金制度を利用し解决することができ ました。実際， 2 年間給与が得られないというのは非常に 厳しいことであり，このことでNPになることを迷った り，断念する看護師もいます。

2016 年， 2 年間の NP 教育課程を 2 期生として修了し, NPの資格を得ました。教育課程の 1 年目は主に解剖生理 や薬理学, 外科的治療を含めた治療方法などについて座学 を受けました。 2 年目は実習であり，これまで看護師とし て働いていた病棟や ICU などで医師と行動をともにし， 彼らの仕事を間近で学ばせていただきました。看護師目線 だけではなく, 医師側から診療を行うことは初めての経験 であり,この実習により, NPとしての勤務内容のイメー ジが得られたと考えます。

$\mathrm{NP}$ としての勤務開始当初, 1 期生 2 名の NPがすでに NP としての勤務を開始していました。その頃はまだ NP の勤務体系が十分に定まっていなかったため, 配属先の麻 酔科や看護部と検討を重ね, 具体的な勤務体系を決めてい きました ${ }^{1)}$. 先述したように, 当院ではNPの所属を看護 部, 業務責任は診療科としています。しかし, 私としては 独立した NP 部門を開設し, 看護部をはじめとした各診療 科や院内の他部門, 大学等と連携し, 業務内容や労働環 境, キャリア形成などを独自で管理, 推進していくことが 理想であると考えます。 あわせて NP を国家資格として認 めていただけたら，NPのアイデンティティが芽生え，こ うした所属や給与などの NP を取り巻くさまざまな問題が 解決に向かうのではないかと考えます。

日本 NP 教育大学院協議会は, 大学院修了後, $1 \sim 2$ 年 
の卒後臨床研修の実施を推奨しています。日本国内の多く の施設では，初期研修医プログラムを参考にしながら各診 療科ローテションを中心とした研修プログラムを行ってい ます。しかし, 当院では, 諸外国で採用されている NPの コンピテンシー（行動特性）を主軸としたプログラムを 行っており，米国クリティカルケア看護師協会 $(\mathrm{AACN})$ が開発した Synergy Model for Patient Care と AdultGerontology Acute Care Nurse Practitioner Competencies を基にしたプログラムを 1 年間実施しています。卒後臨床 研修では，看護師としてこれまで行っていなかった特定行 為や直接指示の実践などの業務を通して, 自身の業務内容 の具体的なビジョンを得ることができました。ささら，わ れわれ NP の存在や業務内容をさまざまな診療科や部門の 方々に知っていただくことができ，スムーズな連携づくり の土台となったと感じています。また，私は卒後臨床研修 中，医局内に自分用のデスクを持たせていただきました。 日々の症例で迷うことや，自分の依頼した指示の是非など を問いたいとき，医局内に居場所があることは非常に便利 で，そのつど医師に質問し，疑問を解決していくことで少 しずつ知識と経験を深められたように感じています.

卒後臨床研修後，個々の希望により，主な業務を行う診 療科に配属となります。NPの活躍の場は多岐にわたり, 周術期のみならず，ターミナルケア，教育部門，地域医療 などさまざまであり，毎年何名かは大学病院に残ります が，中には故郷の病院へ帰る方，開業医のクリニックに勤 務される方などさまざまです，私は周術期，特に病棟での 術前術後の患者管理に関わりたいと考えていたため，心臓 外科配属を希望しました。配属にあたり，主任教授である 松山克彦先生と相談し，具体的な業務内容を決めました。

心臟外科での私の業務内容を述べますと, 毎朝 8 時から の ICU 回診, さらに病棟での医師とのカンファレンスで 1 日の治療方針を確認することから始まります。このとき に退院予定や処方内容の変更などの具体的な指示があり, 私が実行することとなります．カンファレンス後は医師と ともに患者回診ならびに創傷処置を行います．抜糸やド レーン抜去も私が率先して行います。元の後は手術や外来 が始まるため，基本的に病棟は私ひとりになります，病棟 当番の医師はいますが，基本的な業務は私がほとんど行い ます。具体的には入退院時の各種書類の作成, 薬剂や点滴 オーダー，他科へのコンサルテーション，ペースメーカー の設定変更，安静度などの基本的指示の変更などです，さ らに, 患者や家族への退院前の生活指導, 栄養指導の依頼 なども行っています。同時に，病棟看護師や薬剤師，リ八 ビリテーションスタッフからの報告や相談の空口も担いま す．電気的除細動など侵襲的処置においても，処置前の患 者説明や病棟への指示，静脈麻酔管理などを行い，医師と

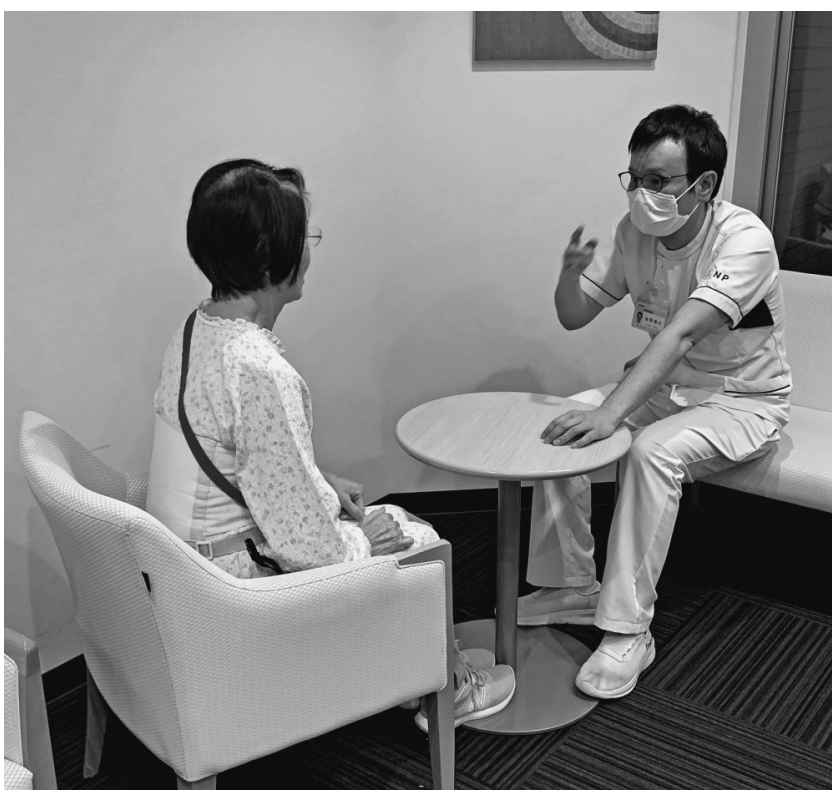

図

協力して治療にあたることもあります。

外来では術前症例の入院準備を行っています。外来より 連絡がきたら，手術内容と手術予定日を医師に確認後，入 院予約，必要な検査などのオーダーと説明，入院後の治療 内容についての説明などを行います。手術に不安を感じて おられる患者や家族が少しでも安心できるようにと，患者 や家族には積極的にコミュニケーションをはかるようにし ています。

看護師にとっては，私は多忙な外科医よりも相談しやす い存在のようで，気軽に声をかけられるので助かっている そうです。また，これまでの集中治療室での経験から，急 変の兆候にいち早く気づけたことで患者の重篤化を防げた こともありました，縱隔炎に対し，正中創の陰圧閉鎖療法 を受けていた患者について，看護師より相談を受け，訪室 すると，すでに血圧低下をきたしており，陰圧療法のチャ ンバー内が血液で充満していることから, 出血性ショック であると判断，治療しつつすぐに医師へ連絡し，手術室へ 搬送したことがありました。他部署ではありますが，集中 治療部では，気管内挿管から始まり人工呼吸器からのウイ ニング，抜管に到るまでの呼吸管理，カテコラミンの調整 や IABP，ECMO，Impella などの心肺補助装置の調整な どの循環管理，動脈圧ラインの留置や動脈血採血といった 処置も麻酔科所属の NP が実施しています。

さらに，日常業務のかたわら，診療看護師を目指す学生 に向けた看護大学院での講義を担当しています。こうした 貴重な経験を通し，教育の重要性を再確認するとともに自 身の学び直しのよい機会にもなっています.

当院は大学病院でありながら心蔵外科医局員は松山教授 を含め 6 名しかいません，日々の予定手術の上に緊急手術 
が続くこともあり，疲弊している先生方のため，周術期管 理や外来, 病棟業務の負担が少しでも軽くなればと 2 年 間，一所懸命勤めさせていただきました．振り返ると自分 が不慣れなばかりに迷惑をかけたり, もっと早くに異変に 気づけたのではないかと悔やまれることもありましたが, 心臟外科の先生方にいつも感謝の言葉をかけていただき, さらに日々の業務で至らない部分を補っていただき, 感謝 の気持ちしかありません. 今後もさらに精一杯業務につと め, 可能であれば, 患者アンケートをもとにした臨床研究 などにも取り組んでいきたいと考えています。

現在, 日本の $\mathrm{NP}$ 数は徐々に増加しており, NP 導入を 行った施設や診療科において, 在院日数や ICU 滞在日数
の短縮といった成果が報告されております。こうした成果 はNP が実施する特定行為がもたらしただけではなく， $\mathrm{NP}$ が持つ向上心や能力が影響しているのではないかと考 えます。

今後も心臟外科領域において, NP と心臟外科医師が良 好に連携し, 心臓血管外科領域の発展に寄与することがで きれば幸いであると考えます。

\section{文献}

1) Kurosawa M, Mori K, Takabayashi $T$ et al. Clinical Practice of Nurse Practitioners in Aichi Medical University Hospital. J Jpn Soc Nurse Pract $2018: 2: 1-7$. 